\title{
PENGARUH LINGKUNGAN SEKOLAH DAN KOMPETENSI PROFESIONAL GURU TERHADAP PRESTASI SISWA MELALUI MOTIVASI BELAJAR SEBAGAI VARIABEL INTERVENING PADA SMAN 2 SEULIMEUM KABUPATEN ACEH BESAR.
}

\author{
Arsalna $^{1}$, Apridar $^{2 *}$, Mohd Heikal $^{3}$ \\ ${ }^{123}$ Program Pasca sarjana Ilmu manajemen, Universitas Malikussaleh, Aceh \\ Email:arsalna2703@gmail.comapridar@yahoo.commohdheikal@unimal.ac.id
}

\begin{abstract}
The purpose of this study was to analyze the influence of the school environment, teacher professional competence on student achievement through learning motivation as an intervening variable at SMAN 2 Seulimeum Aceh Besar District. This study used two stages of sampling, namely the Proportionate stratified random sampling technique and the simple random sampling technique (simple random sampling), which amounted to 156 students. The analysis tool uses the SEM ( structural equation modeling ) A MOS method . the study result showed that variables school environment positive and significant effect on student achievement and motivation, professional competence of teachers and a significant positive effect on student achievement and motivation, and learning motivation also has a positive and significant effect on student achievement. To me see mediation analysis of the school environment and teachers' professional competence and a significant positive effect is partially mediated the achievements of students of SMAN 2 Seulimeum Aceh Besar district.
\end{abstract}

Keywords: school environment, professional competence of teachers, motivation to learn, and student achievement.

\section{PENDAHULUAN}

Kehidupan di era globalisasi ini menuntut setiap negara terus meningkatkan kualitas sumber daya manusia yang dimiliki, dalam upaya meningkatkan kualitas sumber daya manusia diperlukan sebuah mekanisme yang mampu mengoptimalkan berbagai komponen dan sumber daya yang ada. Sumber daya manusia adalah suatu potensi yang dapat dijadikan sebagai aset dan juga dapat difungsikan sebagai modal didalam organisasi. Peningkatan sumber daya manusia yang berkualitas dapat ditempuh salah satunya dengan memanfaatkan dan meningkatkan perkembangan ilmu pengetahuan dan teknologi dengan baik, sehingga mendukung usaha suatu Negara untuk lebih maju dan dapat bersaing dengan Negara-negara lain, sebagaimana usaha yang dilakukan pemerintah Indonesia untuk meningkatkan kualitas sumber daya manusianya adalah melalui pendidikan.

Menurut Irham \& Novan (2013), menjelaskan pendidikan merupakan suatu bentuk usaha mendewasakan dan memandirikan manusia melalui kegiatan yang terencana dan disadari melalui kegiatan belajar dan pembelajaran yang melibatkan siswa dan guru. Selanjutnya, dalam Undang-Undang No. 20 Tahun 2003 juga menjelaskan tentang Sistem Pendidikan Indonesia tertulis, Pendidikan adalah usaha sadar dan terencana untuk mewujudkan suasana belajar dan proses pembelajaran agar 
peserta didik secara aktif mengembangkan potensi dirinya untuk memiliki kekuatan spiritual keagamaan, pengendalian diri, kepribadian, kecerdasan, akhlak mulia, serta keterampilan yang diperlukan dirinya, masyarakat, bangsa dan negara. Banyak pihak yang cukup memperhatikan berbagai kegiatan dan permasalahan yang ada di bidang pendidikan. Karena melalui kegiatan pendidikan kualitas sumber daya manusia di suatu negara dapat ditingkatkan. Dewasa ini sudah menjadi kepentingan dan kebutuhan di setiap negara untuk terus berusaha meningkatkan pembangunannya di bidang pendidikan. Sehingga dari usaha-usaha tersebut dapat tercipta sumber daya manusia yang berkualitas dan mampu mengikuti berbagai kemajuan di bidang ilmu pengetahuan dan teknologi.

Tujuan pendidikan nasional adalah menghasilkan sumber daya manusia yang lebih berkualitas, hal ini dapat diperoleh melalui jalur pendidikan formal yaitu sekolah. Sebagai lembaga pendidikan formal, sekolah sepenuhnya diberikan kewenangan mempertimbangkan seluruh aspek dari proses pembelajaran diantaranya dalam mengadakan kegiatan proses belajar mengajar. Selain itu sekolah juga ikut mengambil bagian dalam menghasilkan siswa atau lulusan yang memiliki kualitas serta karakter yang baik sesuai dengan tujuan pendidikan nasional untuk siap terjun kedunia kerja. Untuk menghasilkan sumber daya manusia yang berkualitas diperlukan adanya usaha di dalam proses pendidikan melalui kegiatan belajar.

Menurut Slameto (2010), menjelaskan prestasi belajar adalah tingkat pengetahuan anak terhadap materi yang diterima. Prestasi belajar yang bagus sangatlah diinginkan oleh siswa yang telah melakukan kegiatan pembelajaran karena dengan prestasi belajar yang bagus dapat memperlihatkan usaha yang telah dilakukan siswa setelah belajar dan siswa tersebut bisa mengukur kemampuan dia dalam memahami pelajaran. Keberhasilan belajar bagi siswa terlihat dari segi kemampuannya ketika menguasai materi pelajaran, prestasi belajar, keterampilan dan kebenaran saat menyelesaikan tugas yang diberikan guru. Tinggi dan rendahnya prestasi belajar yang dicapai siswa menunjukkan tingkat keberhasilan belajarnya, dapat dipengaruhi oleh beberapa faktor, baik dari dalam maupun dari luar diri siswa. Faktor yang membuat siswa SMAN 2 Seulimeum menjadi rendahya prestasi siswa dikarenakan kurangnya siswa dalam memperhatikan penjelasan guru, dikarenakan sebagian siswa dalam kelas sering membuat keributan sehingga siswa lain juga tidak fokus dalam memperhatikan penjelasan materi yang disampaikan guru. Terkadang saat ada juga siswa yang susah dalam belajar justru menggangu teman lain untuk tidak mau belajar, dengan keadaan tersebut membuat siswa jadi pemalas dalam belajar yang justru akan berdampak pada menurunnya prestasi siswa. Selain dari banyaknya gangguan temanteman yang enggan mau mendengarkan materi yang disampaika, namun sebagian siswa juga enggan menulis dan menjawab setiap pertanyaan atau tugas yang diberikan guru. Ada juga hal lain yang membuat prestasi menurun dari segi tidak adanya kompromi dan kerja sama yang baik dalam berpartisipasi dalam mengerjakan tugas kelompok sesama teman antar kelas, dari ketiga hal tersebut yang sudah dipaparkan merupakan faktor yang menyebabkan siswa SMAN 2 seulimeum menunrunnya prestasi siswa dalam proses belajar mengajar. 
Selain itu yang mempengaruhi prestasi belajar siswa diantaranya adalah motivasi. Motivasi belajar dapat diartikan sebagai keseluruhan daya penggerak dari diri siswa, dengan membentuk serangkaian usaha untuk menyediakan suatu kondisi yang dapat menjamin kelangsungan dan memberikan arah yang baik pada kegiatan belajar, sehingga tujuan yang diinginkan oleh subjek belajar itu dapat tercapai. Menurut Hamalik (2013), motivasi adalah suatu bentuk perubahan energi dalam diri seseorang yang dapat ditandai dengan adanya perasaan dan reaksi untuk meraih suatu tujuan tertentu. Peranan motivasi sangat penting dalam peningkatan prestasi belajar siswa, banyak faktor yang mempengaruhi kuat lemahnya motivasi belajar siswa.

Di sisi lain lingkungan sekolah juga salah satu faktor yang memberikan kontribusi paling besar terhadap pencapaian prestasi belajar. Keadaaan lingkungan sekolah yang kondusif akan menwujudkan ketenangan dan kenyamanan dalam belajar sehingga bisa berjalan dengan baik dan mudah dalam memperoleh materi pelajaran secara maksimal. Lingkungan sekolah merupakan bagian dari proses belajar yang menciptakan tujuan mendapatkan ilmu pelajaran. Lingkungan sekolah tidaklah lepas dari keberadaan siswa dalam melakukan kegiatan belajar. Kebiasaan belajar siswa dipengaruhi oleh kebiasaan siswa dalam belajar di sekolah, di rumah maupun di masyarakat. Kebiasaan belajar yang efektif berdampak pada lingkungan belajarnya. Penguatan motivasi yang diberikan guru secara maksimal dapat memperlancar lingkungan belajar yang baik pula. Keberadaan guru yang diakui sebagai motivator atau daya penggerak menjadi sangat penting untuk memacu proses belajar siswa.

Guru dengan kompetensi profesional yang baik mampu menumbuhkan kepribadian siswa karena kepribadian merupakan faktor penting dalam pencapaian tujuan pembelajaran. Sehingga, kompetensi profesional yang dimiliki guru akan mendorongnya untuk mengantarkan siswanya mencapai hasil belajar yang terbaik. Hal ini sejalan dengan teori belajar behavioristik yang memandang bahwa hasil belajar disebabkan karena ada faktor stimulus yang mampu menimbulkan respon pada individu Rifa'i \& Anni (2012). Aktivitas belajar siswa dalam ruangan belajar dapat menwujudkan hasil yang optimal apabila stimulus dirancang sedemikian rupa sehingga mudah direspon oleh siswa. Stimulus ini salah satunya berasal dari guru melalui pembelajaran yang dilakukan. Stimulus berkaitan erat dengan kompetensi professional guru, karena guru dengan kompetensi profesional yang baik akan mampu memilih stimulus yang tepat untuk diberikan kepada siswa, sehingga dapat melahirkan respon positif terhadap objek yang sedang dipelajari.

\section{TINJAUAN PUSTAKA \\ Prestasi Siswa}

Menurut Slameto (2010), prestasi adalah bentuk penerimaan pengetahuan anak materi yang disampaikan. Prestasi belajar yang bagus sangatlah diinginkan oleh siswa yang telah melakukan kegiatan pembelajaran karena dengan prestasi belajar yang bagus dapat memperlihatkan usaha yang telah dilakukan siswa setelah belajar dan siswa tersebut bisa mengukur kemampuan dia dalam memahami pelajaran. Tinggi dan rendahnya prestasi belajar yang didapatkan siswa dapat menunjukkan tingkat 
keberhasilan belajarnya, dapat dipengaruhi oleh beberapa faktor, baik dari dalam maupun dari luar diri siswa.

Menurut opini dari Ahmad prestasi belajar merupakan hasil belajar yang akan menghasilkan suatu target dan tujuan pembelajaran meliputi 3 aspek yakni, Pertama Mengetahui, Kedua terampil melakukan apa yang ia tahu, Ketiga melakukan apa yang ia ketahui dengan rutin dan memperhatikan konsekuen yang ada. Menurut Santoso et al., (2014), mereka menyebutkan bahwa ada enam indikator untuk mengukur prestasi belajar siswa yaitu Memperhatikan penjelasan guru, mencatat materi/soal/hasil pembahasan, menanggapi, mengajukan pertanyaan dan pendapat kepada peneliti/siswa, berdiskusi/berpartisipasi aktif dalam kelompok, mengerjakan LKS, dan menyimak hasil analisis peneliti.

\section{Motivasi belajar}

Pada dasarnya kata motivasi berasal dari Latin "movere" yang berarti daya penggerak, motivasi (Motivation) dalam manajemen hanya ditujukan kepada sumber daya manusia umumnya dan bawahan khususnya. Menurut Robbins (2014), motivasi adalah upaya yang dilakukan untuk mencapai bentuk keinginan dan tujuan yang ingin dicapai dengan mengkondisikan kemampuan dan upaya agar terpenuhi suatu kebutuhan yang dicari oleh seseorang. Menurut Usman (2011), juga menjelaskan motivasi merupakan bentuk keinginan yang terdapat pada seorang untuk merangsang agar melakukan tindakan atau sesuatu yang menjadi alasan seseorang dalam berperilaku. Menurut Thoha (2014), motivasi adalah dorongan yang menyebabkan seseorang mau berusaha mencapai suatu tujuan tertentu yang diinginkan.

Menurut Sardiman (2014) mengemukakan ciri-ciri motivasi yang ada pada siswa di antaranya adalah rajin dalam menghadapi tugas yang berikan, ulet dan mau menghadapi kesulitan (tidak mudah putus asa) tidak menginginkan dorongan dari pihak luar untuk berprestasi sebaik mungkin (tidak mudah puas dengan prestasi yang dicapai), menampakkan keinginan belajar terhadap semua mata pelajaran, dapat mempertahankan pendapatnya, dan senang mencari dan memecahkan masalah.

\section{Lingkungan Sekolah}

Lingkungan sekolah merupakan lingkungan pendidikan utama yang kedua setelah kelurga. Siswa-siswi, guru administrator, konselor hidup bersama dan melaksanakan pendidikan secara teratur dan terencana dengan baik. Menurut Hasbullah (2013), lingkungan sekolah ini merupakan lanjutan dari pendidikan dalam keluarga. Sekolah adalah jembatan bagi siswa dalam mendewasakan diri, berinteraksi dengan baik di lingkungan keluarga dan dapat beradaptasi dengan masyarakat. Apa yang dipelajari di sekolah, diharapkan siswa mampu mengaplikasikan dengan baik. Dengan berbagai peluang belajar dan perkembangan metode belajar siswa didorong pada kurikulum yang dilaksanakan dalam bentuk pembelajaran.

Lingkungan sekolah merupakan faktor penting yang dapat mempengaruhi prestasi seorang siswa dalam proses pembelajaran. Maka Slameto (2010), menjelaskan indikator-indikatornya adalah metode mengajar, relasi guru dengan siswa, disiplin sekolah, relasi siswa dengan siswa dan fasilitas Sekolah. 


\section{Kompetensi Profesional Guru}

Dalam sebuah penelitian yang dilakukan oleh Sudjana (2013), menyatakan kompetensi profesional guru akan mempengaruhi kualitas pengajaran yang dilakukannya. Guru yang memiliki kompetensi profesional yang baik dapat merancang pembelajaran sesuai dengan kondisi dan kebutuhan siswa. Penyusunan dan pelaksanaan program pengajaran yang baik disertai dengan penilaian proses dan hasil pembelajaran akan memudahkan guru untuk mencapai tujuan pembelajaran dengan optimal. Penguasaan yang baik terhadap bahan pengajaran akan mendorong guru untuk menyampaikan materi dengan jelas kepada siswa terlebih apabila didukung dengan penggunaan alat, media, dan metode pembelajaran yang bervariasi, sehingga mampu memacu semangat siswa untuk mengeksplorasi pengetahuan yang dimiliki.

Menurut Rusman (2014), Profesionalisme guru dapat diartikan sebagai bentuk keahlian yang diperoleh seseorang dalam bidang pendidikan dan pembelajaran yang menyangkut tentang sebuah pekerjaan yang ditempuh oleh seseorang. Agar profesionalisme guru tersebut bisa diukur, maka diperlukan beberapa indikator di antaranya memiliki keterampilan mengajar yang baik, memiliki wawasan yang luas, menguasai kurikulum, menguasai media pembelajaran dan menjadi teladan yang baik.

\section{KERANGKA KONSEPTUAL}

Kerangka konseptual merupakan penjelasan keterkaitan atau hubungan suatu teori dengan faktor-faktor penting yang telah diketahui dalam suatu masalah tertentu. Kerangka koseptual dalam penelitian ini dibangun atas dasar pandangan ahli secara teoritis dan hasil penelitian secara empiris. Penelitian ini mencoba meneliti tentang pengaruh lingkungan keluarga, lingkungan sekolah dan kompetensi profesional guru terhadap prestasi siswa melalui motivasi belajar sebagai variabel intervening pada SMAN 2 Seulimeum. Dalam kerangka konseptual ini akan uraikan tentang hubungan antar variabel baik secara teoritis maupun secara empiris (penelitian sebelumnya).

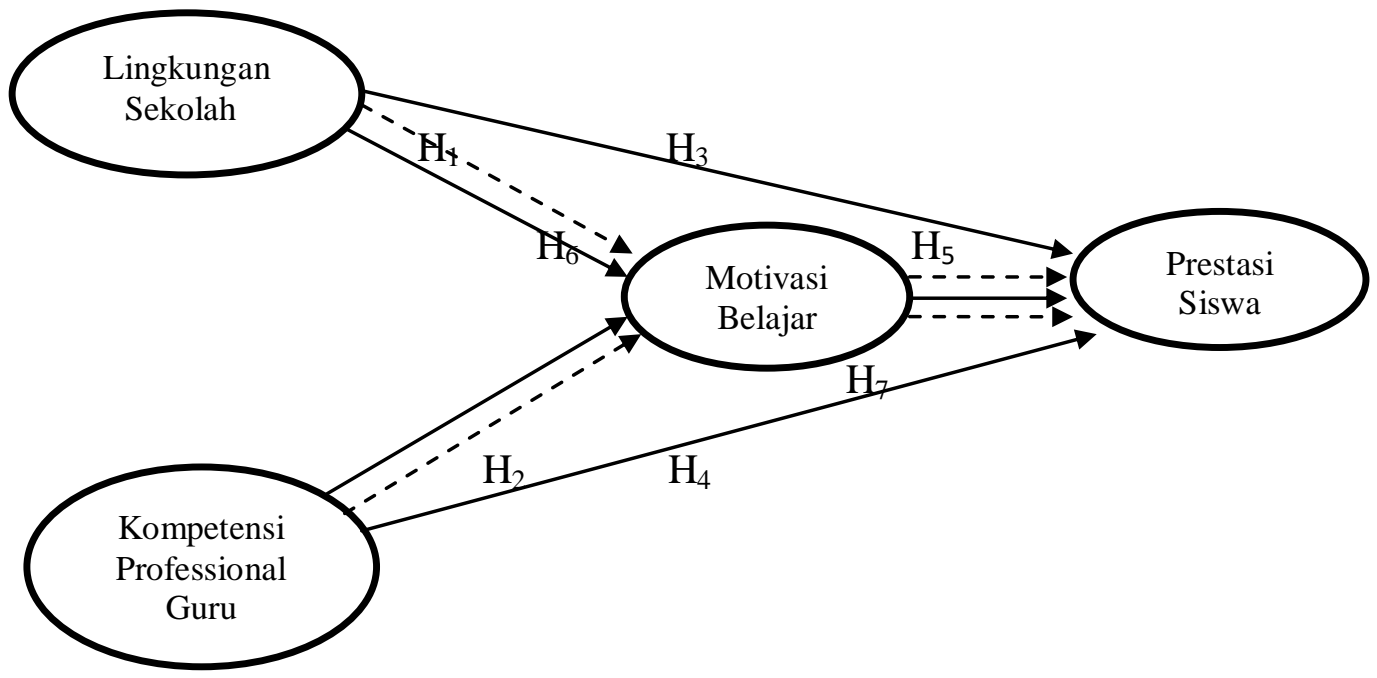

Arsalna, Apridar, Mohd.Heikal 


\section{HIPOTESIS PENELITIAN}

Berdasarkan kerangka konseptual di atas, maka dapat dirumuskan hipotesis dalam penelitian ini adalah sebagai berikut:

H1: Lingkungan sekolah berpengaruh positif terhadap motivasi belajar siswa SMAN 2 Seulimeum.

H2: Kompetensi profesional guru berpengaruh positif terhadap motivasi belajar siswa SMAN 2 Seulimeum

H3: Lingkungan sekolah berpengaruh positif terhadap prestasi siswa SMAN 2 Seulimeum.

H4: Kompetensi profesional guru berpengaruh positif terhadap prestasi siswa SMAN 2 Seulimeum.

H5: Motivasi belajar berpengaruh positif terhadap prestasi siswa SMAN 2 Seulimeum.

H6: Motivasi belajar mampu memediasi pengaruh lingkungan Sekolah terhadap prestasi Siswa SMAN 2 Seulimeum.

H7: Motivasi belajar mampu memediasi pengaruh kompetensi profesional guru terhadap prestasi siswa SMAN 2 Seulimeum.

\section{METODE PENELITIAN}

Variabel bebas dalam penelitian ini adalah lingkungan sekolah dan kompetensi profesional guru. Motivasi belajar sebagai variabel perantara, sedangkan variabel terikatnya adalah prestasi siswa. Tipe penelitian adalah pernyataan dengan menggunakan kuisioner sebagai alat untuk mengambil data. Instrumen penelitian menggunakan skala Likert yang telah dimodifikasi 1-5. Populasi dalam penelitian ini adalah seluruh siswa pada SMA Negeri 2 Seulimeum kabupaten Aceh Besar sebanyak 249 siswa. Pengambilan sampel dilakukan secara dua tahap. Tahap pertama menentukan jumlah sampel 156 siswa dengan menggunakan teknik proportionate stratified random sampling, Penentuan sampel pada tahap kedua dilakukan dengan metode Simple Random Sampling (teknik sampel acak sederhana), dimana setiap siswa mempunyai kesempatan yang sama dengan yang lain untuk dipilih menjadi anggota sampel. Teknik analisis yang digunakan adalah analisis SEM ( Structural Equation Model) dengan menggunakan Program SPSS 16.0 dan Amos 21. Uji validitas konstruk menggunakan Confirmatory Factor Analysis (CFA) masingmasing konstruk dilihat dari nilai Loading Factor setiap indikator dan didapat hasil setiap penyataan memiliki nilai >0,60. Adapun untuk uji reabilitas data dapat menggunakan rumus dibawah ini :

$$
\text { Construct Reliability }=\frac{\left(\sum \text { std.loading }\right)^{2}}{\left(\sum \text { std.loading }\right)^{2}+\sum_{e i}}
$$

Sementara ekstrak varian dapat dihitung dengan rumus sebagai berikut: 


$$
\begin{aligned}
& \text { Variance } \\
& =\frac{\sum \text { std.loading }}{2} \\
& \sum \text { std.loading }+\sum_{e i}^{2}
\end{aligned}
$$$$
\text { Extracted }
$$

\section{HASIL PENELITIAN DAN PEMBAHASAN}

Hasil analisis full model 1 (model awal) dengan menggunakan analisis SEM ditunjukkan pada Gambar 1. Hasil perhitunganya bahwa indeks kesesuaian (goodness of fit index) menunjukkan bahwa dari delapan kriteria yang dievaluasi ternyata hanya dua kriteria yang belum memenuhi (fit) yakni GFI, AGFI, CFI, RMSEA dan Probability.

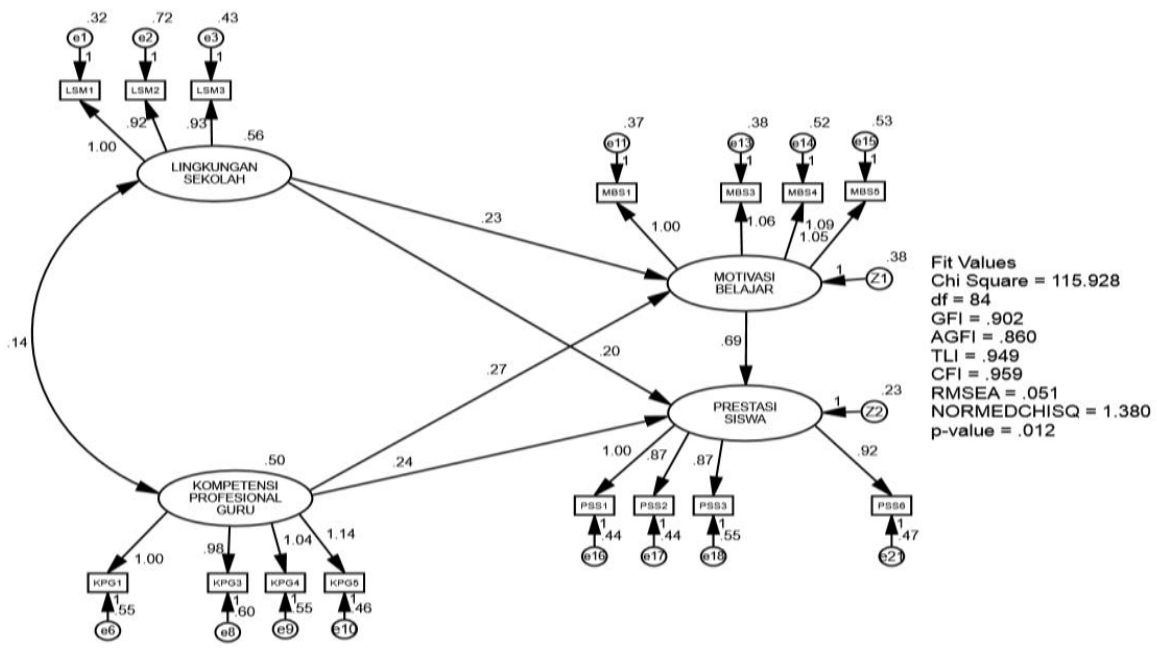

Gambar. 1 Full Model Penelitian Sebelum Modifikasi

Tabel. 1

Goodness of fit Indexs untuk Full Model Sebelum Modifikasi

\begin{tabular}{cccc}
\hline Goodness of Fit Index & Cut-off Value & Hasil Analisis & Evaluasi Model \\
\hline$\chi^{2}$ Chi-Square Statistik & Diharapkan Kecil & 115,928 & Baik \\
Probability & $>0,05$ & 0,012 & Marginal \\
CMIN/DF & $<2.00$ & 84 & Baik \\
GFI & $>0.90$ & 0.902 & Baik \\
AGFI & $>0.90$ & 0.860 & Marginal \\
TLI & $>0.95$ & 0.949 & Baik \\
CFI & $>0.95$ & 0.959 & Baik \\
RMSEA & $<0.08$ & 0,051 & Baik \\
\hline
\end{tabular}

Hasil analisis goodness of fit menunjukkan keseluruhan evaluasi model telah memenuhi kriteria yang ditetapkan, kecuali nilai probability dan AGFI yang masih marginal. Untuk perbaikan nilai goodness of fit menjadi lebih baik perlu dilakukan modifikasi dengan cara menghubungkan antar error yang disarankan Amos dalam indeks modifikasi (Ghozali, 2013). Gambar 2 berikut ini merupakan Gambar full 
model penelitian yang telah dilakukan modifikasi dan Gambar full model tersebut sebagai berikut:

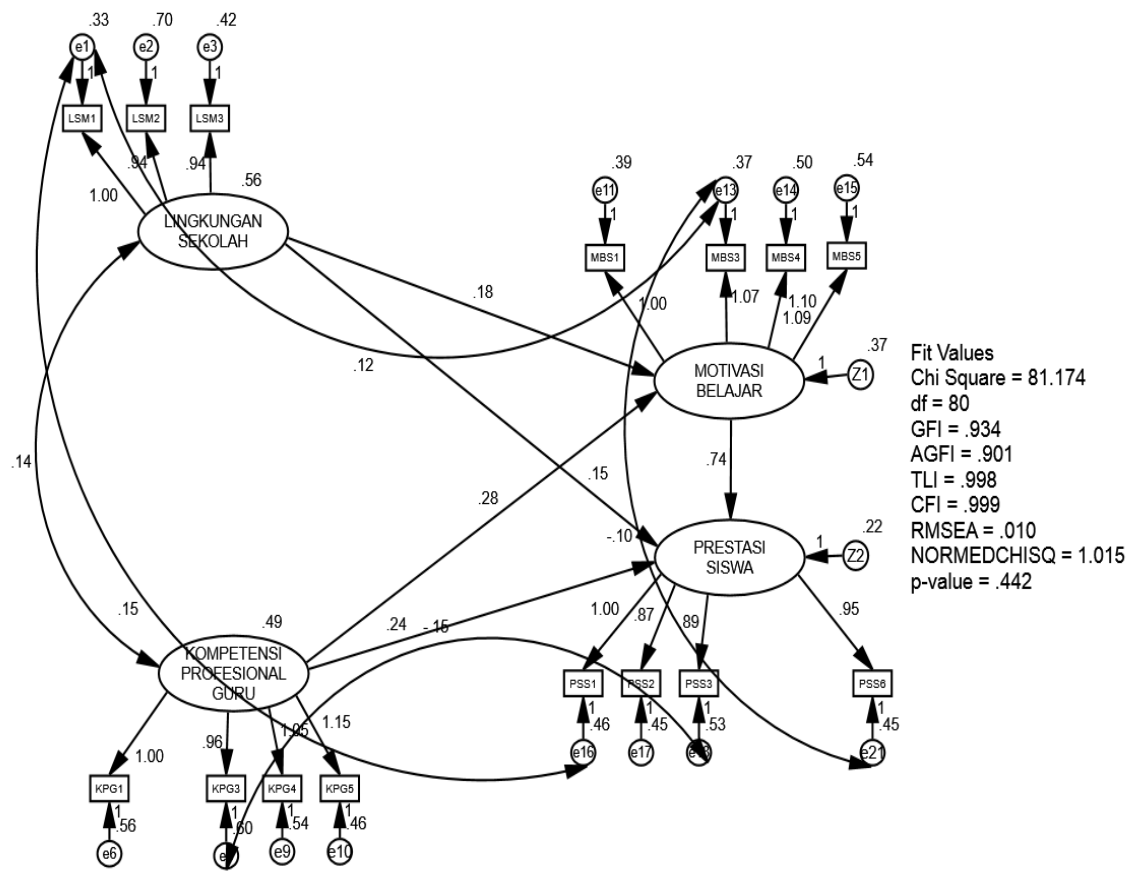

Gambar. 2 Full Model Setelah Modifikasi

Tabel. 2

Goodness of fit Indexs untuk Full Model Setelah Modifikasi

\begin{tabular}{cccc}
\hline Goodness of Fit Index & Cut-off Value & Hasil Analisis & Evaluasi Model \\
\hline$\chi^{2}$ Chi-Square Statistik & Diharapkan Kecil & 81,174 & Baik \\
Probability & $>0,05$ & 0,442 & Baik \\
CMIN/DF & $<2.00$ & 80 & Baik \\
GFI & $>0.90$ & 0.934 & Baik \\
AGFI & $>0.90$ & 0.901 & Baik \\
TLI & $>0.95$ & 0.998 & Baik \\
CFI & $>0.95$ & 0.999 & Baik \\
RMSEA & $<0.08$ & 0,010 & Baik \\
\hline
\end{tabular}

Hasil analisis goodness of fit menunjukkan bahwa setelah dilakukan modifikasi ke semua kriteria nilai yang ditetapkan lebih baik dari sebelumnya. Dengan demikian secara keseluruhan model penelitian ini telah fit dan mendukung data. Untuk melihat seberapa besar pengaruh variabel eksegen (kualitas kehidupan kerja dan lingkungan kerja) terhadap variabel intervening (komitmen organisasi) dan variabel endogen (kinerja guru) ditampilkan dalam Tabel 3:

Tabel. 3 


\section{Pengaruh Variabel Eksogen terhadap Variabel Endogen}

\begin{tabular}{|c|c|c|c|c|c|}
\hline & & Estimate & S.E & C.R & $P$ \\
\hline Motivasi Belajar & $<$ Lingkungan Sekolah & 0,256 & 0,097 & 2,410 & 0,016 \\
\hline Motivasi Belajar & $<$ Kompetensi Profesional Guru & 0,279 & 0,102 & 2,636 & 0,008 \\
\hline Prestasi Siswa & ¿-. Lingkungan Sekolah & 0,190 & 0,094 & 2,139 & 0,032 \\
\hline Prestasi Siswa & <- Kompetensi Profesional Guru & 0,219 & 0,099 & 2,461 & 0,014 \\
\hline Prestasi Siswa & $<$ Motivasi Belajar & 0,599 & 0,123 & 5,629 & $* * *$ \\
\hline
\end{tabular}

Berdasarkan tabel 3 maka dapat dijelaskan bahwa dari 5 pengaruh langsung variabel eksogen terhadap variabel endogen semua berpengaruh signifikan yaitu terdapat pengaruh lingkungan sekolah terhadap motivasi belajar siswa SMAN 2 Seulimeum, pengaruh kompetensi profesional guru terhadap prestasi siswa SMAN 2 Seulimeum, pengaruh kompetensi profesional guru terhadap motivasi belajar siswa SMAN 2 Seulimeum, pengaruh motivasi belajar terhadap prestasi siswa SMAN 2 Seulimeum dan pengaruh lingkungan sekolah terhadap prestasi siswa SMAN 2 Seulimeum.

\section{Uji Efek Mediasi}

Untuk mengetahui pengaruh efek mediasi, maka terlebih dahulu harus bisa melihat seberapa besar pengaruh langsung (direct effect), tidak langsung (indirect effect) dan pengaruh keseluruhan (total effect) antar variabel.

Tabel. 4

Standardized Direct, Indirect \& Total Effects

\begin{tabular}{|c|c|c|c|c|}
\hline & $\begin{array}{l}\text { Linglungan } \\
\text { Sekolsh }\end{array}$ & $\begin{array}{l}\text { Kompetensi } \\
\text { Profesional } \\
\text { Guru }\end{array}$ & Motixasi.Belajagr & Prestasi Siswo \\
\hline \multicolumn{5}{|c|}{ Direct Effect } \\
\hline Motixasi Belajar & 0,256 & 0,279 & 0,000 & 0,000 \\
\hline Prestasi Siswa, & 0,190 & 0,219 & 0,599 & 0,000 \\
\hline \multicolumn{5}{|c|}{ Indirect Effects } \\
\hline Motivasi Belajar & 0,000 & 0,000 & 0,000 & 0,000 \\
\hline Prestasi Siswa & 0,153 & 0,167 & 0,000 & 0,000 \\
\hline \multicolumn{5}{|c|}{ Total Effects } \\
\hline Motivasi Belajar & 0,256 & 0,279 & 0,000 & 0,000 \\
\hline Prestasi Siswa & 0,343 & 0,386 & 0,599 & 0,000 \\
\hline
\end{tabular}

Hasil pengujian efek mediasi (intervening) hubungan variabel lingkungan sekolah dengan variabel prestasi siswa yang dimediasi oleh variabel motivasi belajar ditampilkan dalam bentuk Gambar 3: 


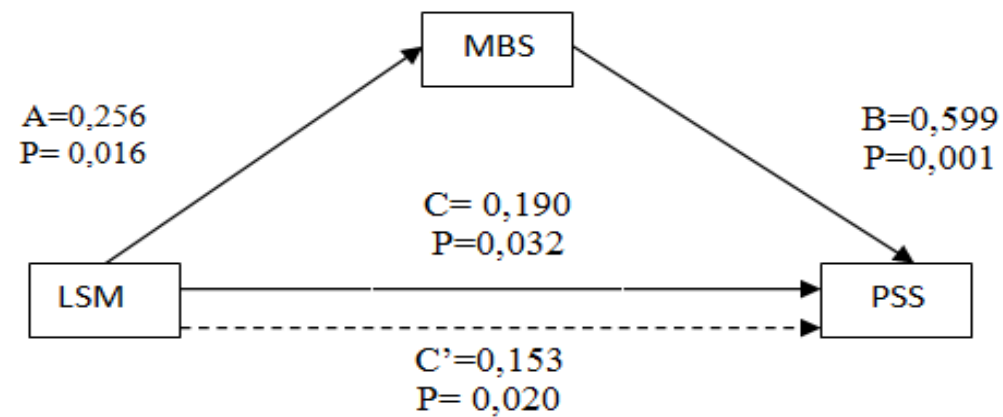

Gambar. 3 Hasil Uji Efek Mediasi LS_MB_PS

Gambar 3 dapat menjelaskan bahwa koefesien jalur A, jalur B dan jalur C, adalah signifikan dan nilai signifikansi jalur $\mathrm{C}^{\prime}$ adalah signifikan. Karena probabilitas jalur $\mathrm{C}^{\prime}$ tidak signifikan, sehingga dapat diartikan terjadinya hubungan parsial mediasi atau variabel motivasi belajar memediasi secara parsial mediasi antara lingkungan sekolah dengan prestasi siswa SMAN 2 Seulimeum Kabupaten Aceh Besar. Hasil penelitian menyatakan bahwa pengaruh langsung lingkungan sekolah terhadap prestasi siswa lebih besar dari pengaruh tidak langsung lingkungan sekolah terhadap prestasi siswa dengan mediasi motivasi belajar (partial medition).

Adapun hasil uji efek mediasi (intervening) hubungan variabel kompetensi profesional guru dengan variabel prestasi siswa yang dimediasi oleh variabel motivasi belajar ditampilkan dalam bentuk Gambar berikut ini:

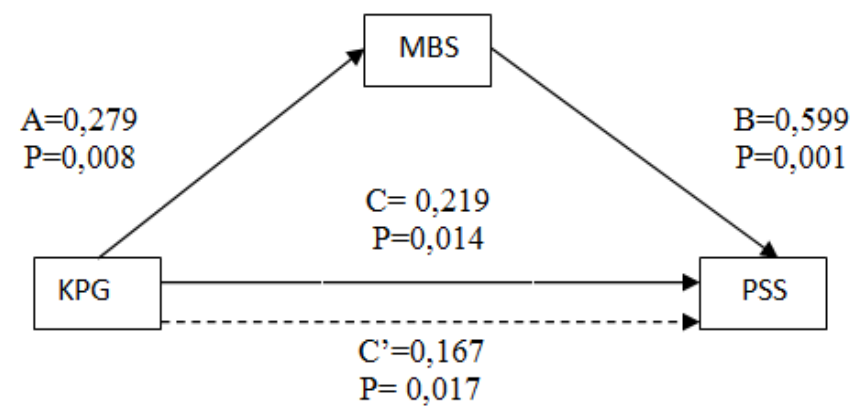

Gambar. 4 Hasil Uji Efek Mediasi KPG_MB_PS

Gambar 4 juga menjelaskan bahwa koefesien jalur A, jalur B dan jalur C, merupakan signifikan dan nilai signifikansi jalur $C^{\prime}$ juga signifikan. Karena probabilitas jalur $\mathrm{C}^{\prime}$ tidak signifikan, sehingga dapat disimpulkan terjadi hubungan parsial mediasi atau dengan kata lain variabel motivasi belajar memediasi secara parsial mediasi antara kompetensi profesional guru dengan prestasi siswa SMAN 2 Seulimeum Kabupaten Aceh Besar. Hasil penelitian menyatakan bahwa pengaruh langsung kompetensi profesional guru terhadap prestasi siswa lebih besar dari pengaruh tidak langsung kompetensi profesional guru terhadap prestasi siswa dengan mediasi motivasi belajar (partial medition).

\section{Tabel 5}

\section{Hasil Uji Hipotesis}




\begin{tabular}{|c|c|c|c|c|c|c|}
\hline No & Pernyataan Hipotesis & $\begin{array}{l}\text { Standard } \\
\text { Estimate }\end{array}$ & S.E. & C.R. & $\mathbf{P}$ & Kesimpulan \\
\hline $\mathbf{1}$ & $\begin{array}{l}\text { Terdapat pengaruh signifikan } \\
\text { Lingkungan Sekolah terhadap } \\
\text { Motivasi belajar Siswa } \\
\text { SMAN } 2 \text { Seulimeum } \\
\text { Kabupaten Aceh Besar. }\end{array}$ & 0,256 & 0,097 & 2,410 & 0,016 & Diterima \\
\hline 2 & $\begin{array}{l}\text { Terdapat pengaruh signifikan } \\
\text { Lingkungan Sekolah terhadap } \\
\text { Prestasi Siswa SMAN } 2 \\
\text { Seulimeum Kabupaten Aceh } \\
\text { Besar. }\end{array}$ & 0,190 & 0,094 & 2,139 & 0,032 & Diterima \\
\hline 3 & $\begin{array}{l}\text { Terdapat pengaruh signifikan } \\
\text { Kompetensi professional } \\
\text { guru terhadap Motivasi } \\
\text { belajar Siswa SMAN } 2 \\
\text { Seulimeum Kabupaten Aceh } \\
\text { Besar. }\end{array}$ & 0,279 & 0,102 & 2,636 & 0,008 & Diterima \\
\hline 4 & $\begin{array}{l}\text { Terdapat pengaruh signifikan } \\
\text { Kompetensi professional } \\
\text { guru terhadap Prestasi Siswa } \\
\text { SMAN } 2 \text { Seulimeum } \\
\text { Kabupaten Aceh Besar. }\end{array}$ & 0,219 & 0,099 & 2,461 & 0,014 & Diterima \\
\hline 5 & $\begin{array}{l}\text { Terdapat pengaruh signifikan } \\
\text { Motivasi Belajar terhadap } \\
\text { Prestasi Siswa SMAN } 2 \\
\text { Seulimeum Kabupaten Aceh } \\
\text { Besar. }\end{array}$ & 0,599 & 0,123 & 5,629 & 0,000 & Diterima \\
\hline 6 & $\begin{array}{l}\text { Terdapat pengaruh signifikan } \\
\text { Lingkungan Sekolah terhadap } \\
\text { Prestasi Siswa melalui } \\
\text { Motivasi Belajar SMAN } 2 \\
\text { Seulimeum Kabupaten Aceh } \\
\text { Besar }\end{array}$ & 0,153 & 0,066 & 2,320 & 0,020 & Diterima \\
\hline 7 & $\begin{array}{l}\text { Terdapat pengaruh signifikan } \\
\text { Kompetensi Profesional Guru } \\
\text { terhadap Prestasi Siswa } \\
\text { melalui Motivasi Belajar } \\
\text { SMAN } 2 \text { Seulimeum } \\
\text { Kabupaten Aceh Besar. }\end{array}$ & 0,167 & 0,070 & 2,384 & 0,017 & Diterima \\
\hline
\end{tabular}

\section{Implikasi Teoritis}

Penelitian ini menghasilkan beberapa implikasi secara teoritis yaitu sebagai berikut:

1. Hasil penelitian ini menyatakan bahwa variabel lingkungan sekolah berpengaruh signifikan terhadap motivasi belajar siswa SMAN 2 Seulimeum Kabupaten Aceh Besar. Hasil ini telah memperkuat dan menambah jumlah literatur ilmiah dalam lingkup teori manajemen sehubungan dengan pengaruh variabel lingkungan sekolah terhadap motivasi melajar. 
Hasil penelitian ini menyatakan bahwa variabel lingkungan sekolah berpengaruh signifikan terhadap prestasi siswa SMAN 2 Seulimeum Kabupaten Aceh Besar. Hasil ini telah memperkuat dan menambah jumlah literature ilmiah dalam lingkup teori manajemen sehubungan dengan pengaruh variabel lingkungan sekolah berpengaruh positif dan signifikan terhadap prestasi siswa SMAN 2 Seulimeum Kabupaten Aceh Besar.

2. Hasil penelitian ini menyatakan bahwa variabel kompetensi profesional guru berpengaruh signifikan terhadap motivasi belajar siswa. SMAN 2 Seulimeum Kabuapten Aceh Besar. Hasil ini telah memperkuat dan menambah jumlah literatur ilmiah dalam lingkup teori manajemen sehubungan dengan pengaruh variabel kompetensi profesional Guru terhadap motivasi belajar.

Hasil penelitian ini menyatakan bahwa variabel kompetensi profesional guru berpengaruh signifikan terhadap prestasi siswa SMAN 2 Seulimeum Kabupaten Aceh Besar. Hasil ini telah memperkuat dan menambah jumlah literatur ilmiah dalam lingkup teori manajemen sehubungan dengan pengaruh variabel kompetensi profesional guru berpengaruh positif dan signifikanterhadap prestasi siswa SMAN 2 Seulimeum Kabupaten Aceh Besar.

3. Hasil penelitian ini menyatakan bahwa variabel motivasi belajar berpengaruh positif dan signifikan terhadap prestasi siswa SMAN 2 Seulimeum Kabuapten Aceh Besar. Hasil ini telah memperkuat dan menambah jumlah literatur ilmiah dalam lingkup teori manajemen sehubungan dengan pengaruh variabel motivasi belajar terhadap Prestasi siswa SMAN 2 Seulimeum Kabupaten Aceh Besar.

4. Hasil penelitian ini menyatakan bahwa variabel motivasi belajar memediasi secara signifikan pengaruh lingkungan sekolah terhadap prestasi siswa SMAN 2 Seulimeum Kabupaten Aceh Besar. Mediasi ini parsial mediasi (partial mediation). Hasil ini telah memperkuat dan menambah jumlah literatur ilmiah dalam menganalisis variabel mediasi dalam suatu penelitian. Namun peran motivasi belajar dalam memediasi lingkungan sekolah terhadap prestasi siswa berpengaruh lemah dibandingkan dengan pengaruh langsung antara lingkungan sekolah terhadap prestasi siswa SMAN 2 Seulimeum.

Hasil penelitian ini menyatakan bahwa variabel motivasi belajar memediasi secara positif dan signifikan pengaruh kompetensi profesional guru terhadap Prestasi siswa SMAN 2 Seulimeum Kabupaten Aceh Besar. Mediasi ini juga parsial mediasi (Partial mediation) Hasil ini telah memperkuat dan menambah jumlah literatur ilmiah dalam menganalisis variabel mediasi dalam suatu penelitian. Namun peran motivasi belajar dalam memediasi kompetensi profesional guru terhadap prestasi siswa berpengaruh lemah dibandingkan dengan pengaruh langsung antara kompetensi profesional guru terhadap prestasi siswa SMAN 2 Seulimeum.

\section{Implikasi Praktis}

Penelitian ini menghasilkan beberapa implikasi secara praktis yaitu sebagai berikut: 
1. Hasil penelitian ini menyatakan bahwa variabel lingkungan sekolah berpengaruh signifikan terhadap motivasi belajar siswa SMAN 2 Seulimeum Kabupaten Aceh Besar. Ini dikarenakan Lingkungan Sekolah secara umum sudah berlangsung baik Hal ini berimplikasi bahwa variabel lingkungan Sekolah merupakan salah satu variabel predictor yang perlu diperhatikan Pimpinan Sekolah dalam meningkatkan motivasi belajar siswa SMAN 2 Seulimeum.

Hasil penelitian ini menyatakan bahwa variabel lingkungan sekolah berpengaruh signifikan terhadap prestasi siswa SMAN 2 Seulimeum Kabupaten Aceh Besar. Ini dikarenakan lingkungan sekolahsecara umum sudah berlangsung baik. Hal ini berimplikasi bahwa variabel lingkungan sekolah merupakan salah satu variabel prediktor yang perludiperhatikan Pimpinan Sekolah dalam meningkatkan prestasi siswa SMAN 2 Seulimeum.

2. Hasil penelitian ini menyatakan bahwa variabel kompetensi profesional guru berpengaruh signifikan terhadap motivasi belajar siswa SMAN 2 Seulimeum Kabupaten Aceh Besar. Ini dikarenakan kompetensi profesional guru secara umum sudah berlangsung baik. Hal in berimplikasi bahwa variabel kompetensi profesional guru merupakan salah satu variabel prediktor yang perlu diperhatikan Pimpinan Sekolah dalam meningkatkan motivasi belajar siswa SMAN 2 Seulimeum.

Hasil penelitian ini menyatakan bahwa variabel kompetensi profesional guru berpengaruh signifikan terhadap prestasi siswa SMAN 2 Seulimeum

Kabupaten Aceh Besar. Ini dikarenakan kompetensi professional guru secara umum sudah berlangsung baik. Hal ini berimplikasi bahwa variabel kompetensi profesional guru merupakan salah satu variabel prediktor yang perlu diperhatikan Pimpinan Sekolah dalam meningkatkan prestasi siswa SMAN 2 Seulimeum.

3. Hasil penelitian ini menyatakan bahwa variabel motivasi belajar berpengaruh signifikan terhadap prestasi siswa SMAN 2 Seulimeum Kabuapten Aceh Besar. Ini dikarenakan motivasi belajar secara umum sudah berlangsung baik. Hal ini berimplikasi bahwa variabel motivasi belajar merupakan salah satu variabel prediktor yang perlu diperhatikan Pimpinan sekolah dalam meningkatkan prestasi siswa SMA 2 Seulimeum.

4. Hasil penelitian ini menyatakan bahwa variabel motivasi belajar memediasi secara signifikan pengaruh lingkungan sekolah terhadap prestasi siswa SMAN 2 Seulimeum Kabupaten Aceh Besar. Mediasi ini parsial mediasi (partial mediation). Ini dikarenakan mediasi motivasi lingkungan sekolah parsial mediasi maka berimplikasi bahwa variabel motivasi belajar merupakan salah satu variabel prediktor yang perlu diperhatikan Pimpinan Sekolah dalam meningkatkan prestasi siswa SMAN 2 Seulimeum.

Hasil penelitian ini menyatakan bahwa variabel motivasi belajar memediasi secara signifikan pengaruh kompetensi profesional guru terhadap prestasi siswa SMAN 2 Seulimeum Kabupaten Aceh Besar. Mediasi ini parsial mediasi (partial mediation). Ini dikarenakan mediasi motivasi belajar antara kompetensi profesional guru parsial mediasi maka berimplikasi bahwa variabel motivasi 
belajar merupakan salah satu variabel yang perlu diperhatikan Pimpinan Sekolah dalam meningkatkan prestasi siswa SMAN 2 Seulimeum.

\section{KESIMPULAN}

1. Lingkungan sekolah berpengaruh positif dan signifikan terhadap motivasi belajar. Hal ini berarti semakin baiklingkungan sekolah maka akan semakin baik pula motivasi belajar siswa SMAN 2 Seulimeum.

2. Lingkungan sekolah berpengaruh positif dan signifikan terhadap prestasi siswa.Hal ini berarti semakin baik lingkungan sekolah maka akan semakin baik pula prestasi siswa SMAN 2 Seulimeum.

3. Kompetensi profesional guru berpengaruh positif dan signifikan terhad motivasi belajar. Hal ini berarti semakin baik kompetensi profesional guru maka semakin baik pula motivasi belajar siswa SMAN 2 Seulimeum.

4. Kompetensi profesional guru berpengaruh positif dan signifikan terhadap prestasisiswa. Hal ini berarti semakin baik kompetensi profesional guru makasemakin baik pula prestasi siswa SMAN 2 Seulimeum.

5. Motivasi belajar berpengaruh positif dan signifikan terhadap prestasi siswa.. Hal ini berarti semakin baik motivasi belajar maka semakin baik pula prestasi siswa SMAN 2 Seulimeum.

6. Motivasi belajar memediasi secara signifikan hubungan antara lingkungan sekolah dengan prestasi siswa SMAN 2 Seulimeum Kabupaten Aceh Besar. Hasil penelitian dapat dilihat dari nilai probabilitas $0,020<0,05$ membuktikan bahwa motivasi belajar masih kurang baik untuk dapat dijadikan perantara untuk mempengaruhi hubungan lingkungan sekolah dalam meningkatkan prestasi siswa karena pengaruhnya parsial mediasi.

7. Motivasi belajar memediasi secara signifikan hubungan antara kompetensi profesional guru dengan prestasi siswa SMAN 2 Seulimeum Kabupaten Aceh Besar. Hasil penelitian dapat dilihat dari nilai probabilitas 0,017 $<0,05$ membuktikan bahwa motivasi belajar masih kurang baik untuk dapat dijadikan perantara untuk mempengaruhi hubungan kompetensi profesional guru untuk meningkatkan prestasi siswa karena pengaruhnya parsial mediasi.

\section{DAFTAR PUSTAKA}

Achmad, Rifa'I dan Catharina, T. Anni. 2012. Psikologi Pendidikan. Semarang: UNNES Press.

Hamalik, Oemar. 2013. Proses Belajar Mengajar. Jakarta : PT.Bumi Aksara. Hasbullah. 2013. Dasar-dasar Ilmu Pendidikan. Jakarta : Rajawali Pers.

Irham, Muhammad dan Novan Ardy. 2013. Psikologi Pendidikan Teori dan Aplikasi dalam Proses Pembelajaran. Yogyakarta: AR-RUZZ Media.

Robbins, Stephen P dan Timothy A Judge. 2014. Perilaku Organisasi. Jakarta: Salemba Empat.

Rusman. (2014). Model-model Pembelajaran (Mengembangkan Profesionalisme Guru). Jakarta: Raja Grafindo Persada. 
JURNAL MANAJEMEN INDONESIA (J-MIND)

(ISSN.2503.4367)

Vol.5 No. 1 Januari-Juni 2020

Santoso, Singgih. (2011). Structural Equation Modeling (SEM) konsep dan aplikasi dengan Amos 18. Jakarta: PT Media Kompotindo.

Sardiman. 2014. Interaksi Dan Motivasi Belajar Mengajar. Jakarta: PT Raja Grafindo Persada.

Sudjana, Nana. 2013. Dasar-Dasar Proses Belajar Mengajar. Bandung: Sinar Baru Algensindo

Thoha, Miftah. 2014. Perilaku Organisasi : Konsep Dasar dan Aplikasinya, cetakan ke-23. Jakarta : Rajawali Pers.

Usman, Husaini. (2011). MANAJEMEN (Teori, Praktek, dan Riset Pendidikan). Jakarta:Bumi Aksara. 